\title{
Industry-Level Stock Returns Response to COVID-19 News
}

L.C.M. Phuong

Industrial University of Hochiminh City, Hochiminh, Vietnam

\begin{abstract}
The COVID-19 pandemic has impacted the stock markets of many countries. Understanding the impact of this pandemic on industries is an important and relevant basis for a thorough explanation of stock market movements during this period. The aim of this study is to examine how stock returns of non-financial sectors in Vietnam's stock market react to information about the COVID-19 pandemic. The event study method is applied to analyze three main events related to the emergence and outbreak of this pandemic in Vietnam in 2020. The first event (January 23, 2020) and the second event (March 6, 2020), respectively, were the time when Vietnam officially announced that it had recorded the first case positive for COVID-19 in the Hochiminh city and Hanoi. The third event is on March 30, 2020, Vietnam announced that it will apply a blockade order in all provinces and cities nationwide to limit the outbreak of this pandemic. Closing price data from January 1, 2019 to April 14, 2020 for five industry indexes (Basic Materials, Consumer Goods, Consumer Services, Industry and Utilities), used in this study. The results show that the stock prices of all five sectors reacted in the same meaningful direction (negative/positive) after the event that Vietnam confirmed the first patient confirmed with COVID-19 in Hochiminh city and the nationwide blockade event was announced, proving that the stock market is affected by psychology. In industries, Industry and Consumer Services are the two sectors that respond the most to events, but Basic materials are the least affected. The study found that the Consumer Goods industry had the most positive results in the five industries for the following two events; The Utilities industry reacted negatively to the first information that could create potential risks of a COVID-19 outbreak in the community, especially in the two major economic centers of Vietnam. Conclusions from this study show that Vietnam's stock market is inefficient, research results and insights on industry responses to disease information contribute to strategic planning for policymakers and investors in the future.
\end{abstract}

Keywords: COVID-19; industry response; blockade; event study; signalling theory; behavioural finance; efficient market; Vietnam

For citation: Phuong L.C.M. Industry-level stock returns response to COVID-19 news. Finance: Theory and Practice. 2022;26(1):103-114. DOI: 10.26794/2587-5671-2022-26-1-103-114

\section{Реакция доходности акций на новости о COVID-19 на отраслевом уровне}

Л.Ц.М. Пхуонг
Промышленный университет города Хошимин, Хошимин, Вьетнам

\begin{abstract}
АННОТАЦИЯ
Пандемия COVID-19 повлияла на фондовые рынки многих стран. Понимание влияния этой пандемии на отрасли является важной и актуальной основой для тщательного объяснения движения фондового рынка в этот период. Цель данного исследования - изучить, как доходность акций нефинансовых секторов фондового рынка Вьетнама реагирует на информацию о пандемии COVID-19. Автор применяет метод исследования событий для анализа трех основных событий, связанных с появлением и вспышкой пандемии COVID-19 во Bьетнаме в 2020 г. Первое событие (23 января 2020 г.) и второе событие (6 марта 2020 г.), соответственно, - это время, когда Вьетнам официально объявил о регистрации первого случая положительного результата на COVID-19 в городе Хошимин и столице Ханой. Третье событие - 30 марта 2020 г., когда Вьетнам объявил о том, что введет полный локдаун во всех провинциях и городах страны, чтобы ограничить вспышку пандемии. В исследовании использованы данные по ценам закрытия для пяти отраслевых индексов (сырье и основные материалы, потребительские товары, потребительские услуги, промышленность и коммунальные услуги) с 1 января 2019 г. по 14 апреля 2020 г. Результаты показывают, что цены акций всех пяти секторов отреагировали в одном и том же значимом направлении (отрицательном/положительном) после того, как во Вьетнаме был подтвержден
\end{abstract}

(c) Phuong L.C.M., 2022 
первый пациент с COVID-19 в городе Хошимин и объявлен общенациональный локдаун, что доказывает, что на фондовый рынок влияет психология. Что касается отраслей, то промышленность и потребительские услуги - это два сектора, которые больше всего реагируют на события, а сырье и основные материалы подвержены наименьшему влиянию. Сделан вывод, что отрасль потребительских товаров имела наиболее положительные результаты на следующие два события; отрасль коммунальных услуг негативно отреагировала на первую информацию, которая могла создать потенциальный риск вспышки COVID-19 в обществе, особенно в двух основных экономических центрах Вьетнама. Выводы данного исследования показывают, что фондовый рынок Вьетнама является неэффективным. Результаты исследования и понимание реакции отраслей на информацию о заболеваниях могут быть использованы при стратегическом планировании политиками и инвесторами в будущем.

Ключевые слова: COVID-19; реакция промышленности; локдаун; исследование событий; сигнальная теория; поведенческие финансы; эффективный рынок; Вьетнам

Для цитирования: Phuong L.C.M. Industry-level stock returns response to COVID-19 news. Финансы: теория и практика. 2022;26(1):103-114. DOI: 10.26794/2587-5671-2022-26-1-103-114

\section{INTRODUCTION}

Research on Pandemic Pasts [1] concludes that no infectious disease has yet to forcefully affect the stock market like the COVID-19 pandemic- 19. Current COVID-19 studies are mainly focused on China [2], the United States [3] and some developed countries $[4,5]$, however, for developing countries whose stock markets are ranked in emerging or frontier markets, the number publication is still few. In addition, a few recent studies on the impact of COVID-19 in undeveloped stock markets are prioritized for the financial sector [6] or the pharmaceutical industry [7], so the overall picture of the impact of the pandemic on industries in these markets is not yet available. Vietnam is a country that has most of its border with China - a country that was heavily affected by COVID-19 in early 2020, so it cannot avoid the negative impact of this pandemic. Affected by the COVID-19 pandemic, VNIndex fell $-32.85 \%$ from the beginning of 2020 to 649.1 points on March 31, 2020. This is the lowest point of VNIndex since 2017. It can be seen that for unexpected events, psychological factors will influence the behavior of investors very strongly, and this is clearly reflected in price fluctuations in the stock market [2]. However, Vietnam is one of the few countries in the world with positive economic growth in $2020 .{ }^{1}$ From this fact, it is very important to understand the short-term movements of stock prices by sectors regarding COVID-19 developments in Vietnam and motivates the author to carry out this study. Therefore, this article will focus on studying how the COVID-19 pandemic has impacted the short-term response of sectors on the Vietnamese stock market in the early period of 2020.

\footnotetext{
${ }^{1}$ World Bank. Taking Stock, July 2020: What Will Be the New Normal for Vietnam? The Economic Impact of COVID-19. Washington DC: World Bank; 2020. August. DOI: 10.1596/34268
}

To measure the short-term impact at the industry level caused by the COVID-19 pandemic, the first two official announcements about the risk of disease outbreaks in Hochiminh city and Hanoi and the nationwide blockade order for the first time in Vietnam, is used to analyze the reaction of stock prices on the Vietnamese stock market. These three events will be used to survey five non-financial industries: Basic Materials, Consumer Goods, Consumer Services, Industry and Utilities. The industry's response to each announcement is measured by cumulative extraordinary returns based on the event research methodology. The industry's response to each announcement is measured by cumulative abnormal returns based on the event research methodology. The results from the study are expected to suggest investors, corporate managers and policy makers to make better decisions in the future.

\section{LITERATURE REVIEW}

The efficient market theory states that a market is said to be efficient when stock price movements are random, stock returns are unpredictable, so the set of returns is stocks over time tend to follow a normal distribution. Based on a theoretical review and empirical studies [8], shows that the adjustment of stock prices in the market is classified based on three levels of information as weak form, semi-strong form and strong form. All historical information is reflected in stock prices that are characteristic of weak-form efficient markets. Stock prices reflect both historical information and all publicly available information, which is characteristic of the semistrong form. Compared with the semi-strong form, in the strong form, the amount of information reflected in the stock price is supplemented with information that investors have obtained through exclusive access. Therefore, a market is said to be efficient 
(strong form) when stock prices in the market already reflect all information [8], so that investors will not be able to obtain an abnormal return based on this information [9]. In other words, the behavior of investors according to the efficient market theory is economic people and they always act rationally.

Behavioral finance theory: A study of decisions in uncertain situations $[10,11]$ has shown that decisions are not entirely "economic people" as in efficient market theory whose decisions are influenced by psychological bias. Behavioral finance theory implicitly assumes that the information structure and characteristics of market participants influence investor decisions [12]. Therefore, this theory is often used to explain the existence of abnormal returns in financial markets [13].

Signaling theory, first applied to employment decisions in the labor market [14], has been used to explain information asymmetry in many real-life situations. economics [15]. This theory was quickly applied to explain the decisions of stock investors in the financial markets [16], especially when combined with the event research method [17]. When an unexpected event occurs, the investor - the recipient of the information - interprets the impact of these events. As a result, investor behavior will be reflected in trading results in the stock market [18]. Using the event study method [19] points out that legal scandals related to top managers have been published that have caused the share prices of this company and other companies in the same industry to fall sharply. It implies that investors interpreted the event as an industry-wide risk signal rather than merely corporate risk directly related to the event. Information related to public health [18] argues that the signal theory that can explain events about the COVID-19 pandemic has increased the risk for both companies in the sector. financial and nonfinancial sectors. This is evident by the stock-specific risk-return relationship being positive in the results of [18]. In other words [18] would like to emphasize that during the pandemic, rising stock prices are a signal that reflects the expectation that the performance of these companies will also increase.

\section{IMPACT OF COVID-19 ON INDUSTRY IN SOME COUNTRIES}

Basic materials industry: The impact of COVID-19 on the Basic Materials industry has been realized in several countries such as China [2], New Zealand [4]; Turkey [5]; United States [3] and Vietnam [20] but the results are not quite the same. Using the event study method, the results of studies in a number of countries have shown that the stock prices of the Basic materials industry react to information related to the COVID 19 outbreak [2, 4, 5]. The closure of Wuhan on January 23, 2020 and the WHO warning about COVID-19 as a global pandemic had a negative impact on the Basic Materials industry on the Chinese stock market, respectively [2] and the Turkish stock market [5]. Following news that New Zealand announced a blockade to prevent the development of COVID-19 in the community [4] indicates that the profit of the Basic Materials industry is alternating between increases and decreases. This shows the fluctuation of investor sentiment towards this event. Using Google search volume to measure investors' attention to information related to COVID-19 [3] found that as investors increased focus on COVID-19 and/or an increase in COVID-19 cases will negatively impact the industry. In addition, the more sources reporting on COVID-19, the more negative impact on the profits of the Basic Materials industry, conversely, the more the word "Panic" is mentioned in the news, the more impact it will have on the bottom line. positively on the profitability of this industry [21].

Consumer Service Industry: Research on the United States stock market [22] show that both the event including the shutdown of Wuhan and the event that China confirmed this pneumonia of unknown cause can be transmitted from person to person, both neutral impact on the Consumer Services industry. But the share price of this industry fell sharply on the event that Italy announced the blockade on February 23, 2020 [22]. Further investigating sub-sectors in Turkey [5] pointed out that the Wholesale-Retail and Sports-Entertainment industries both showed negative cumulative abnormal returns around the day WHO warned COVID-19 was a global pandemic, in which, Sports-Entertainment and recreation is the more affected sub-sector. Similar to $[2,5]$ using the New Zealand Stock Exchange COVID-19 event study method also shows that the cumulative abnormal returns of the Sports-Entertainment sector are negative for the window $(-10 ; 0)$, but is positive for the Wholesale-Retail industry. Travel and direct clothing retail are likely to remain negatively impacted until the COVID-19 pandemic is contained, while online retailers (like Amazon) will benefit during the pandemic [23].

Consumer Goods Industry: Using the dependent variable as return of the Consumer Goods industry, five days after the COVID-19 lockdown as five dummy variables and some other control variables in the regression equation [4] shows that the regression coefficients of the dummy variables are statistically significant. In which, day $t=1 ; 3$ after the lockdown is greater than zero, otherwise, the regression coefficient at day $t=2 ; 4 ; 5$ is less than zero. This result implies 
that the news that the lockdown in New Zealand due to COVID-19 has affected the return of the Consumer Goods industry and the impact is alternating between positive and negative. Research with many different events [24] shows that cumulative abnormal returns for stocks of food manufacturing companies were negative only when Vietnam announced the detection of the first patient infected with the virus. COVID-19 but this sector's stock reacted positively to the next events. In the US, google search volume for COVID-19 positively impacted the Consumer Goods industry profits at event date in both the single model and the model using the number of new infections as the control variable [3]. However, [3] shows that the first difference in google search volume for COVID-19 negatively affects the return of this industry for both the model with or without the control variable. Consumer Goods subsector study [23] shows that the return of durable household goods in the United States is negatively impacted by the COVID-19 crisis even when under control macro variables. Measuring the impact of COVID-19 by analyzing more than 19,000 global news sources chronologically [21] shows that the Consumer Goods industry responds positively to gossip related to the panic about COVID-19.

Industrials: Gossips expressing fear over COVID-19 positively impact industry returns [21], conversely, daily changes in search volume on google related to COVID-19 (daily new infections controlled) positive impact on industry return [3]. Using the same event study method $[2,5]$ indicates that events related to COVID-19 have all impacted the share price of the Industry. [5] shows that Industry's cumulative abnormal return fell the most on +/- 5 days around the day WHO declared COVID-19 a pandemic - and then the force from this announcement wanes. Using the Wuhan closure date (January 23, 2020) as the event date [2] shows that the industry abnormal returns are less affected at the event date, the cumulative abnormal return is positive for event windows $(-30.0) ;(-20 ; 0)$; $(-10 ; 0) ;(0 ; 20) ;(0 ; 30)$. This result shows that both before and after the Wuhan closure event, a positive impact on China Industry stock returns. Using industry characteristics as the control variable [4] shows that 3/5 days after New Zealand's lockdown has a significant impact on industry return. Specifically, day 1 and day 4 have a positive impact, on the contrary, day 2 has a positive impact on the return of the industry. Different from studies showing the direct impact of the COVID-19 pandemic on the Industry [23] points out that businesses related to production equipment, machinery and electronic equipment suffer indirect effects from COVID-19. Therefore, these industries will only recover when the macro economy recovers, not just the COVID-19 pandemic is under control [23].

Utilities Industry: The response of Utilities returns to the COVID-19 pandemic has been inconsistent. P. He, Y. Sun, Y. Zhang, T. Li [2] studies the response of industries to the COVID-19 event in China. The results showed that the Utilities sector was one of the industries with the strongest positive abnormal returns on the day of the event. However, the days before and after the event had no significant impact on the industry's abnormal returns. In contrast to [2], research by [3] shows that the return of the Utilities industry is negatively affected by the change in google search volume about the COVID-19 pandemic. Research by [4] shows the alternating positive and negative effects after the day New Zealand announced the blockade due to COVID-19. In addition, [21] shows an increase in the level of talk about the COVID-19 panic that positively impacts Utilities stock returns, but the proportion of sources about COVID-19 has a negative impact on the return of this industry. Studying the evolution of COVID-19 in the United States according to three events, [22] argue that the profit of the Utilities industry increased sharply with the event of Wuhan closure (Incubation phase) and China confirmed that COVID-19 can be transmitted through close contact (outbreak phase) because the customers of this industry are mainly domestic, not dependent on the global market. Moreover, the demand for their products is not affected much by the outbreak of disease [22]. However, as investors sold off stocks due to growing United States recession fears ahead of Italy's COVID-19 lockdown announcement (Fever phase), these stocks underperformed effectively [22].

Based on a review of previous studies, it can be seen that the impact of COVID-19 on the response of each industry is very different between countries. In addition, studies have mainly focused on a sub-discipline rather than a major one $[2,5,20,23]$ therefore, the impact of the pandemic on the whole industry has not been seen. It can be seen that using the results from these studies to apply to Vietnam is not feasible, so this article will investigate based on the five industry indexes - the composite index of all listed companies. listed in each of these industries - for research. The events selected by this article are guaranteed to follow closely with the COVID-19 outbreak situation in Vietnam, so the reality will be higher.

\section{RESEARCH METHODS AND DATA Research Methods}

The event study method is often used to empirically test the relationship between stock prices and events. 
Based on the results of calculating abnormal returns, accumulating abnormal returns and performing tests to evaluate the impact of each event on stock price changes. Models used to calculate abnormal returns include: mean adjusted model; market adjusted model; and market model [25, 26]. The mean adjusted model assumes that a security's interest rate, risk premium, and risk are constant over time. Therefore, the abnormal return is calculated as the difference between the actual return of a security and the estimate from historical data, often with large deviations when the market volatility occurs on the day of the event [27]. The market adjusted model, which assumes that previously expected returns are the same for all securities [26] has shown its limitation when it comes to calculating abnormal returns. The market model is the most commonly used model in event studies. The advantage of this model is the abnormal return has a smaller variance than the raw return. This makes statistical tests more robust [28] and more predictive [29]. Therefore, this study will use a market model to calculate abnormal returns.

Calculate raw return

$$
r_{i t}=\ln \frac{\left(P_{i, t}+D_{i, t}\right)}{P_{i, t-1}}
$$

Similar to $[2,6,28,29]$, this paper uses the market model to calculate the normal rate of return.

$$
R_{i, t}=\alpha_{i, t}+\beta_{i} R_{m, t}
$$

Calculate the average abnormal return as the difference between the raw return and the normal return.

$$
A R_{i, t}=r_{i, t}-\left(\alpha_{i, t}+\beta_{i} R_{m, t}\right)
$$

Calculate the cumulative abnormal return in the event window $\left(t_{1} ; t_{2}\right)$ as the total abnormal return of between $t_{1}$ and $t_{2}$.

$$
C A R_{i\left(t_{1}, t_{2}\right)}=\sum_{t=t_{1}}^{t_{2}} A R_{i, t}
$$

In which:

$P_{i, t} ; P_{i, t-1}$ is the daily closing price of stock i at day $t$ and day $(t-1) ; D_{i, t}$ is the dividend of stock i on the ex-dividend date $t$.

$r_{i, t}$ is the crude return of stock $\mathrm{i}$ at day $\mathrm{t}$, and is taken as the logarithm of the sum of $P_{i, t}$ and $D_{i, t}$ relative to $P_{i, t-1}$. .$\alpha_{i} ; \beta_{i}$, is the coefficient of freedom and the coefficient of regression from equation (2), respectively; $\mathrm{Rm}, t$ is the market rate of return.

$A R_{i, t}$ is the average abnormal return of stock $i$ at day $t$. $C A R_{i}\left(t_{1} ; t_{2}\right)$ is the cumulative abnormal return of stock $i$ in the event window from $t_{1}$ to $t_{2}$.

Events and event windows: VNIndex has had many trading days with sharp declines in 2020, especially in Q1. At the end of the first quarter of 2020, VNIndex closed at 662.26 points, down $-31.5 \%$ compared to 966.67 points as the closing price on January 2, 2020. The days that VNIndex dropped the most in 2020 included: $-3.27 \%$ (the biggest drop in January 2020); -6.48\% (March 9, 2020); -6.27\% (March 23, 2020) and $-5.45 \%$ (July 27,2020 ). When compared with the developments in the fight against COVID-19 in Vietnam, the days when the VNIndex dropped sharply were all related to infections in the community, which led to the outbreak of this disease (Table 1).

This article will use three events related to the emergence and outbreak of COVID-19 in Vietnam in early 2020 and examine its impact on share prices of five sectors in the stock market. After the WHO in China reported cases of pneumonia of unknown cause detected in Wuhan city ${ }^{2}$ [31], on January 23, 2020, Vietnam recorded the first case positive for this disease in Hochiminh city ${ }^{3}$ [32]. Because January 23, 2020 is the 29th day of the Lunar New Year, coinciding with the longest holiday of the year for Vietnamese people, the event date for the first event is used as the first trading day after the Lunar New Year holiday. The second event was the time when Vietnam recorded the first patient infected with COVID-19 in Hanoi on March 6, 2020. ${ }^{4}$ The third event was on March 30, 2020 , Vietnam announced a 15-day blockade order in all provinces and cities nationwide to prevent the outbreak of COVID-19. ${ }^{5}$ The blockade event in Danang

${ }^{2}$ World Health Organization -WHO. Novel Coronavirus (2019nCoV): SITUATION REPORT 1. 2020:1-5. ULR: https:// www.who.int/docs/default-source/coronaviruse/situationreports/20200121-sitrep-1-2019-ncov.pdf(accessed on 05.6.2021). ${ }^{3}$ Nhandan. Ho Chi Minh City strives to maintain role as Vietnam's economic engine. 2020. URL: https://en.nhandan. vn/business/item/9185402-ho-chi-minh-city-strives-tomaintain-role-as-vietnam\%E $2 \% 80 \% 99$ s-economic-engine. html (accessed on 05.6.2021).

${ }^{4}$ Dung T. VN confirms 17th COVID-19 infection case, first in Ha Noi. 2020. ULR: http://news.chinhphu.vn/Home/ VN-confirms-17th-COVID 19-infection-case-first-in-HaNoi/20203/39076.vgp (accessed on 05.6.2021).

${ }^{5}$ Quynh N.X., Uyen N.D.T. Vietnam Orders 15-day Nationwide Isolation from April 1. 2020. URL: https://www. bloomberg.com/news/articles/2020-03-31/vietnamorders-15-day-nationwide-isolation-from-april-1 (accessed on 05.06.2021). 
Statistics of VNIndex's decrease related to COVID-19 events in Vietnam

\begin{tabular}{|l|l|l|}
\hline \multicolumn{1}{|c|}{ Events } & \multicolumn{1}{|c|}{ Description } & \multicolumn{1}{c|}{ VNIndex } \\
\hline $\begin{array}{l}\text { January 23, 2020 (29 } \\
\text { Lunar New Year) }\end{array}$ & $\begin{array}{l}\text { The first patient infected with COVID-19 was } \\
\text { recorded in Vietnam }\end{array}$ & $\begin{array}{l}\text { On January 30, 2020, the first day after the } \\
\text { Lunar New Year holiday, VNIndex -3.27\%, } \\
\text { the strongest decrease in January }\end{array}$ \\
\hline March 6, 2020 & $\begin{array}{l}\text { The first patient infected with COVID-19 was } \\
\text { recorded at Truc Bach street - Hanoi }\end{array}$ & $\begin{array}{l}\text { On March 9, 2020, VNIndex decreased } \\
-6.48 \%\end{array}$ \\
\hline March 30,2020 & $\begin{array}{l}\text { Vietnam announced a nationwide 15-day } \\
\text { lockdown due to COVID-19 }\end{array}$ & $\begin{array}{l}\text { On March 23, 2020, VNIndex decreased } \\
-6.27 \%\end{array}$ \\
\hline July 26, 2020 & $\begin{array}{l}\text { Danang City announced a blockade order due to } \\
\text { COVID-19 }\end{array}$ & On July 27, 2020, VNIndex fell -5.45\% \\
\hline
\end{tabular}

Source: compiled by the author.

city showed little impact on Vietnam's stock market [6], so this article does not present the results of this event on stock prices of all sectors.

Event windows: To be able to compare the impact of each event on the stock market sectors, event windows are used that range from 5 days before each event to the event date and from the event date to 10 days after each event.

\section{Data:}

VNIndex is used as the general index of Vietnam stock market. The data sample is the daily closing price of VNIndex and industry indexes collected from January 2, 2019 to April 14, 2020. In which, the estimated time is the daily transaction data for one year before the event occurs. Five industries are used index of five industries including Basic Materials; Consumer Goods; Consumer Services; Industry; Utilities. The full daily frequency industry index calculated by FiinPro (http://fiinpro.com/) is used in this article. VNIndex's daily closing price is collected at https://www.bloomberg.com/quote/VNINDEX: IND

\section{RESULTS AND DISCUSSION}

The results from the three events are presented in Tables 2, 3, 4. For each event, interpretation and discussion of the results are shared in this section.

Event on January 23, 2020:

Information about the first COVID-19 infection in Vietnam announced before the Lunar New Year holiday has been reflected in the days after this holiday. Of the five studied industries, there are two industries that achieved abnormal returns significantly greater than zero at day $t=0$ and $t=1$, namely Basic Materials $(\mathrm{AR}[0]=1.3 \%)$ and
Utilities $(\mathrm{AR}[1]=1.4 \%)$, respectively. However, the cumulative abnormal returns $[0 ; t]$ with $t \geqslant 3$ of all five industries are significantly less than zero. The largest cumulative abnormal returns after the first event date of the industries are: Consumer services $(\operatorname{CAR}[0 ; 3]=-9.1 \%)$; Industry $(\operatorname{CAR}[0 ; 4]=-6.3 \%)$; Consumer goods (CAR[0;4] $=-6.1 \%)$; Basic Materials $(\operatorname{CAR}[0 ; 3]=4.9 \%)$ and Utilities $(\operatorname{CAR}[0 ; 4]=-3.9 \%)$.

After Vietnam recorded the first case of COVID-19, the stock price of the Basic Materials industry with negative cumulative abnormal returns was similar to the reaction of the Oil and Gas industry [20]. Unlike [20] the abnormal return of the Basic Materials industry is significantly positive at the event date, while the Oil and Gas industry is not. This difference may be because the Basic Materials industry is mainly affected by COVID-19, while the Oil and Gas industry is under the double impact of both the COVID-19 epidemic and the negative impact of world oil prices. Since the market capitalization of Food-Beverage companies accounts for about $90 \%$ of the total market capitalization of the Consumer Goods industry, the cumulative abnormal return of Food-Beverage companies [24] negative is the main reason for the abnormal return of the Consumer Goods industry to be negative. The initial reaction of the shares of Basic Materials and Utilities was positive but quickly fell more sharply in the following days, similar to the reaction of the rest of the sectors, showed the herd behavior of investors. They are strongly influenced by psychological factors. Results from the first event of industries support the prospect theory in behavioral finance by [11].

Event on March 6, 2020:

The reaction of industry stocks to the news that Hanoi recorded the first case of COVID-19 infection 
Results of abnormal return (AR) and cumulative abnormal return (CAR) for the event on January 23, 2020

\begin{tabular}{|c|c|c|c|c|c|}
\hline & \multicolumn{5}{|c|}{ Event on January 23, 2020} \\
\hline AR & Basic Materials & Consumer Goods & $\begin{array}{l}\text { Consumer } \\
\text { Services }\end{array}$ & Industrials & Utilities \\
\hline-5 & -0.002 & -0.001 & -0.007 & -0.001 & -0.006 \\
\hline-4 & 0.001 & -0.005 & 0.005 & $-0.009^{*}$ & -0.010 \\
\hline-3 & 0.001 & -0.001 & 0.000 & -0.001 & -0.007 \\
\hline-2 & 0.007 & 0.002 & -0.001 & 0.002 & 0.001 \\
\hline-1 & 0.003 & -0.001 & 0.002 & -0.004 & 0.007 \\
\hline 0 & $0.013^{*}$ & -0.003 & -0.003 & -0.002 & 0.002 \\
\hline 1 & -0.005 & $-0.014^{* * *}$ & $-0.024^{* * *}$ & -0.004 & $0.014^{* *}$ \\
\hline 2 & $-0.020^{* *}$ & $-0.018^{* * *}$ & $-0.03^{* * *} 4$ & -0.008 & $-0.021^{* * *}$ \\
\hline 3 & $-0.024^{* * *}$ & $-0.011^{* * *}$ & -0.033 & $-0.035^{* * *}$ & $-0.021^{* * *}$ \\
\hline 4 & 0.004 & $-0.017^{* * *}$ & 0.005 & $-0.017^{* * *}$ & -0.011 \\
\hline 5 & -0.001 & 0.000 & 0.002 & $0.019^{* * *}$ & 0.003 \\
\hline 6 & $0.018^{* *}$ & -0.001 & 0.001 & 0.001 & $0.020^{* * *}$ \\
\hline 7 & -0.009 & $0.014^{* * *}$ & $0.013^{* *}$ & 0.003 & 0.001 \\
\hline 8 & 0.002 & 0.001 & $-0.014^{* *}$ & 0.001 & $0.013^{* *}$ \\
\hline 9 & -0.005 & -0.005 & 0.002 & 0.000 & -0.008 \\
\hline 10 & 0.001 & 0.001 & 0.004 & $0.013^{* *}$ & 0.004 \\
\hline CAR & Basic Materials & Consumer Goods & $\begin{array}{l}\text { Consumer } \\
\text { Services }\end{array}$ & Industrials & Utilities \\
\hline$[-5 ; 0]$ & 0.009 & -0.006 & -0.002 & -0.012 & -0.014 \\
\hline$[-4 ; 0]$ & 0.011 & -0.005 & 0.005 & -0.012 & -0.009 \\
\hline$[-3 ; 0]$ & 0.011 & 0.000 & 0.000 & -0.003 & 0.002 \\
\hline$[-2 ; 0]$ & 0.010 & 0.001 & 0.001 & -0.002 & 0.008 \\
\hline$[0 ; 2]$ & $-0.024^{* *}$ & $-0.033^{* * *}$ & $-0.058^{* * *}$ & -0.012 & -0.007 \\
\hline$[0 ; 3]$ & $-0.049^{* * *}$ & $-0.043^{* * *}$ & $-0.091^{* * *}$ & $-0.046^{* * *}$ & $-0.028^{* *}$ \\
\hline$[0 ; 4]$ & $-0.044^{* * *}$ & $-0.061^{* * *}$ & $-0.086^{* * *}$ & $-0.063^{* * *}$ & $-0.039^{* * *}$ \\
\hline$[0 ; 5]$ & $-0.045^{* * *}$ & $-0.060^{* * *}$ & $-0.084^{* * *}$ & $-0.044^{* * *}$ & $-0.036^{* *}$ \\
\hline$[0 ; 6]$ & -0.027 & $-0.061^{* * *}$ & $-0.082^{* * *}$ & $-0.042^{* * *}$ & -0.016 \\
\hline$[0 ; 7]$ & $-0.036^{*}$ & $-0.048^{* * *}$ & $-0.069^{* * *}$ & $-0.039^{* * *}$ & -0.015 \\
\hline$[0 ; 8]$ & -0.034 & $-0.047^{* * *}$ & $-0.083^{* * *}$ & $-0.038^{* * *}$ & -0.002 \\
\hline$[0 ; 9]$ & $-0.039^{*}$ & $-0.052^{* * *}$ & $-0.082^{* * *}$ & $-0.038^{* *}$ & -0.009 \\
\hline$[0 ; 10]$ & -0.038 & $-0.051^{* * *}$ & $-0.078^{* * *}$ & -0.025 & -0.005 \\
\hline
\end{tabular}

Source: authors' calculations. 
Results of abnormal return (AR) and cumulative abnormal return (CAR) for the event on March 6, 2020

\begin{tabular}{|c|c|c|c|c|c|}
\hline \multirow[b]{2}{*}{ AR } & \multicolumn{5}{|c|}{ Event on March 6, 2020} \\
\hline & Basic Materials & Consumer Goods & $\begin{array}{l}\text { Consumer } \\
\text { Services }\end{array}$ & Industrials & Utilities \\
\hline-5 & 0.000 & $0.013^{* * *}$ & -0.001 & -0.005 & -0.007 \\
\hline-4 & 0.001 & 0.006 & $-0.013^{*}$ & 0.008 & $0.019^{* * *}$ \\
\hline-3 & 0.008 & 0.000 & 0.000 & $0.018^{* * *}$ & -0.002 \\
\hline-2 & 0.000 & -0.002 & $0.012^{*}$ & $0.010^{*}$ & -0.010 \\
\hline-1 & -0.004 & 0.002 & $0.011^{*}$ & $0.010^{*}$ & -0.003 \\
\hline 0 & -0.002 & -0.001 & $-0.013^{*}$ & 0.001 & -0.005 \\
\hline 1 & -0.005 & -0.005 & $-0.016^{* *}$ & $-0.032^{* * *}$ & 0.006 \\
\hline 2 & $0.016^{* *}$ & $0.011^{* *}$ & -0.003 & 0.002 & $-0.022^{* * *}$ \\
\hline 3 & -0.006 & 0.006 & $0.022^{* * *}$ & 0.004 & -0.010 \\
\hline 4 & 0.002 & 0.006 & $0.018^{* * *}$ & $-0.020^{* * *}$ & 0.004 \\
\hline 5 & 0.001 & $-0.012^{* * *}$ & -0.008 & $-0.028^{* * *}$ & -0.009 \\
\hline 6 & 0.012 & $0.010^{* *}$ & 0.002 & 0.001 & $0.038^{* * *}$ \\
\hline 7 & 0.011 & $-0.010^{* *}$ & 0.006 & -0.001 & 0.006 \\
\hline 8 & 0.001 & -0.006 & 0.009 & $0.016^{* * *}$ & $-0.014^{*}$ \\
\hline 9 & -0.007 & $-0.017^{* * *}$ & $-0.013^{*}$ & $-0.011^{* *}$ & 0.002 \\
\hline 10 & -0.011 & $0.014^{* * *}$ & $0.035^{* * *}$ & 0.005 & $0.039^{* * *}$ \\
\hline CAR & Basic Materials & Consumer Goods & $\begin{array}{l}\text { Consumer } \\
\text { Services }\end{array}$ & Industrials & Utilities \\
\hline$[-5 ; 0]$ & 0.006 & -0.008 & 0.009 & $0.040^{* * *}$ & -0.003 \\
\hline$[-4 ; 0]$ & 0.006 & 0.005 & 0.011 & $0.045^{* * *}$ & 0.004 \\
\hline$[-3 ; 0]$ & 0.004 & -0.001 & $0.023^{* *}$ & $0.037^{* * *}$ & -0.015 \\
\hline$[-2 ; 0]$ & -0.004 & -0.001 & $0.023^{* *}$ & $0.019^{* *}$ & -0.013 \\
\hline$[0 ; 2]$ & 0.010 & 0.005 & $-0.019^{* *}$ & $-0.030^{* * *}$ & -0.016 \\
\hline$[0 ; 3]$ & 0.005 & 0.011 & $-0.041^{* * *}$ & $-0.026^{* * *}$ & $-0.026^{* *}$ \\
\hline$[0 ; 4]$ & 0.007 & $0.017^{*}$ & $-0.059^{* * *}$ & $-0.045^{* * *}$ & -0.022 \\
\hline$[0 ; 5]$ & 0.008 & 0.005 & $-0.067^{* * *}$ & $-0.073^{* * *}$ & $-0.031^{*}$ \\
\hline$[0 ; 6]$ & 0.020 & 0.016 & $-0.065^{* * *}$ & $-0.072^{* * *}$ & 0.007 \\
\hline$[0 ; 7]$ & 0.031 & 0.005 & $-0.059^{* * *}$ & $-0.074^{* * *}$ & 0.014 \\
\hline$[0 ; 8]$ & 0.032 & 0.000 & $-0.051^{* * *}$ & $-0.058^{* * *}$ & 0.000 \\
\hline$[0 ; 9]$ & 0.025 & -0.017 & -0.063 & $-0.069^{* * *}$ & 0.002 \\
\hline$[0 ; 10]$ & 0.014 & -0.003 & -0.028 & $-0.065^{* * *}$ & $0.041^{*}$ \\
\hline
\end{tabular}

Source: authors' calculations. 
Table 4

Results of abnormal return (AR) and cumulative abnormal return (CAR) for the event on March 30, 2020

\begin{tabular}{|c|c|c|c|c|c|}
\hline \multirow[b]{2}{*}{ AR } & \multicolumn{5}{|c|}{ Event on March 30, 2020} \\
\hline & Basic Materials & Consumer Goods & Consumer Services & Industrials & Utilities \\
\hline-5 & -0.001 & -0.006 & -0.011 & $-0.012^{*}$ & 0.007 \\
\hline-4 & 0.007 & $0.014^{* * *}$ & 0.001 & 0.006 & $0.025^{* * *}$ \\
\hline-3 & $-0.014^{*}$ & 0.000 & -0.008 & 0.002 & -0.009 \\
\hline-2 & $-0.029^{* * *}$ & 0.007 & $-0.019^{* * *}$ & $-0.013^{*}$ & $-0.014^{*}$ \\
\hline-1 & $-0.014^{*}$ & 0.004 & $-0.019^{* * *}$ & -0.006 & -0.003 \\
\hline 0 & $0.020^{* * *}$ & 0.004 & $0.013^{* *}$ & -0.004 & 0.008 \\
\hline 1 & 0.011 & -0.002 & 0.002 & 0.003 & -0.006 \\
\hline 2 & -0.003 & 0.001 & -0.003 & 0.004 & -0.006 \\
\hline 3 & -0.007 & 0.002 & 0.000 & -0.004 & 0.003 \\
\hline 4 & -0.002 & 0.004 & -0.010 & 0.008 & -0.003 \\
\hline 5 & -0.009 & $0.014^{* * *}$ & 0.004 & 0.003 & -0.010 \\
\hline 6 & -0.001 & 0.004 & -0.004 & 0.000 & 0.004 \\
\hline 7 & 0.003 & -0.002 & 0.003 & $0.012^{*}$ & $0.020^{* * *}$ \\
\hline 8 & $0.015^{* *}$ & 0.002 & $0.027^{* * *}$ & $0.013^{*}$ & 0.002 \\
\hline 9 & 0.004 & $-0.010^{* *}$ & $0.032^{* * *}$ & $0.011^{*}$ & 0.000 \\
\hline 10 & $0.020^{* * *}$ & $0.010^{* *}$ & $-0.013^{* *}$ & -0.004 & -0.009 \\
\hline CAR & Basic Materials & Consumer Goods & Consumer Services & Industrials & Utilities \\
\hline$[-5 ; 0]$ & $-0.051^{* * *}$ & $0.020^{*}$ & $-0.055^{* * *}$ & -0.023 & 0.006 \\
\hline$[-4 ; 0]$ & $-0.050^{* * *}$ & $0.026^{* * *}$ & $-0.044^{* * *}$ & -0.011 & -0.002 \\
\hline$[-3 ; 0]$ & $-0.057^{* * *}$ & 0.012 & $-0.045^{* * *}$ & -0.017 & $-0.026^{* *}$ \\
\hline$[-2 ; 0]$ & $-0.043^{* * *}$ & $0.011^{*}$ & $-0.037^{* * *}$ & $-0.018^{*}$ & -0.017 \\
\hline$[0 ; 2]$ & 0.008 & 0.000 & -0.001 & 0.007 & -0.013 \\
\hline$[0 ; 3]$ & 0.001 & 0.002 & 0.000 & 0.003 & -0.010 \\
\hline$[0 ; 4]$ & -0.001 & 0.006 & -0.011 & 0.011 & -0.013 \\
\hline$[0 ; 5]$ & -0.009 & $0.020^{*}$ & -0.007 & 0.014 & -0.023 \\
\hline$[0 ; 6]$ & -0.010 & $0.023^{* *}$ & -0.012 & 0.015 & -0.019 \\
\hline$[0 ; 7]$ & -0.008 & $0.022^{*}$ & -0.008 & 0.026 & 0.001 \\
\hline$[0 ; 8]$ & 0.008 & $0.023^{*}$ & 0.019 & $0.039^{* *}$ & 0.002 \\
\hline$[0 ; 9]$ & 0.011 & 0.014 & $0.052^{* *}$ & $0.050^{* *}$ & 0.002 \\
\hline$[0 ; 10]$ & 0.031 & 0.023 & $0.038^{*}$ & $0.046^{* *}$ & -0.007 \\
\hline
\end{tabular}

Source: authors' calculations. 
on March 6, 2020, had different divergences. All 16 recovered COVID-19 patients in Vietnam announced in the 3rd week of February 2020 could be the explanation for the accumulated abnormal profits of the Consumer Services and Industry sectors. are all significantly positive prior to the second event date. At the event date, only the abnormal returns of Consumer Services industry are $-1.3 \%$ statistically significant. It shows that the Consumer Services sector has reacted very quickly to this new information compared to the rest. After the event date, except for the cumulative abnormal profit of the Basic Materials industry which is not statistically significant, the Consumer Goods industry has CAR $[0 ; 4]=+1.7 \%$, the remaining three industries accumulated abnormal returns are negative. The fact that stock prices reacted in opposite directions before and after the events of March 6, 2020 is reflected in the cumulative abnormal return for the Consumer Services industry $(\operatorname{CAR}[-2 ; 0]=+2.3 \%$ vs. $\operatorname{CAR}[0 ; 5]=-6.7 \%)$ and Industry $(\operatorname{CAR}[-4 ; 0]=+4.5 \%$ vs. $\operatorname{CAR}[0 ; 7]=-7.4 \%)$ showed relevant information COVID-19 has a rapid and strong impact on these two industries. Signals from published information can be interpreted by investors based on their understanding of the disease that has been reported by the media. The disease caused by COVID-19 is a new disease without a vaccine (at the beginning of 2020), which can lead to death and is easily transmitted in the community between people through close contact. In Vietnam, consumer-related services are mainly provided directly at stores, workers of the processing industry are often concentrated in production with high density, so public information about the case of COVID-19 infection implies the health risks and economic losses that are present if there is contagion in these industries. The results from the second event support the signal theory.

Event on March 30, 2020:

On March 30, 2020, Vietnam announced a nationwide blockade order due to COVID-19 starting from the first day of April 2020. Abnormal returns of all five industries are significant before the event date (Table 4), of which only the abnormal return of the Consumer Goods industry is positive $(\mathrm{CAR}[-5 ; 0]=+2.0 \% ; \mathrm{CAR}[-4 ; 0]=+2.6 \%$; $\operatorname{CAR}[-2$; $0]=+1.1 \%$ ) has shown the excessive anxiety of stock investors when the provinces and cities detected positive cases of COVID-19. It can be seen that the negative economic impact on businesses related to the COVID-19 outbreak is reflected much more slowly than the response of investor sentiment. Therefore, this result supports prospect theory. Two out of five industries had significant abnormal returns at the event date: Basic Materials $(\mathrm{AR}[0]=+2.0 \%)$ and Consumer
Services $(\mathrm{AR}[0]=+1.3 \%)$. Ten trading days after the event date, the cumulative abnormal returns of the Basic Materials industry and the Utilities industry are not statistically significant. This result is different from [2] on the Chinese stock market. P. He, Y. Sun, Y. Zhang, T. Li [2] shows that the cumulative abnormal returns of the Basic Materials industry (mining) are all negative with the event windows (before the event, at the event and after the event). Different from the cumulative abnormal returns that alternately increase and decrease after the event date for sectors on the New Zealand stock market [4], the cumulative abnormal returns of the three industries include Consumer Goods, Consumer Services and Industry on Vietnam's stock market were all meaningful positives after the event day. In which, the largest cumulative abnormal return of the Consumer Goods industry is CAR[0; $6]=\operatorname{CAR}[0 ; 8]=+2.3 \%$ ), the Consumer Services industry is $\operatorname{CAR}[0 ; 9]=+5.2 \%$ and Industry is $\operatorname{CAR}[0 ; 9]=5 \%$. The positive reaction after the event showed an increase in confidence of stock investors in the government's blockade measures. The implication from this result supports prospect theory and signal theory.

\section{CONCLUSIONS AND IMPLICATIONS Conclusions}

The purpose of this article is to examine the reaction of stock returns across sectors in the stock market to the first news about COVID-19 outbreaks in Vietnam. Accumulated abnormal returns in the event research methodology are used to measure industry responses to individual events. The first COVID-19 patients were recorded in Hochiminh City and Hanoi, and the announcement of the nationwide blockade were the three events considered for five non-financial industries. These sectors include Basic Materials, Consumer Goods, Consumer Services, Industry and Utilities. Research results show that all five industries reacted negatively after the event that Hochiminh city recorded the first patient infected with COVID-19 and responded positively after the nationwide blockade order was announced supporting the behavioral finance theory. The reaction between industries has clearly diverged to the information that Hanoi recorded the first case of infection (the second event) and before the time when Vietnam applied the nationwide blockade order, which can be explained by the theory signal. In general, across industries, the Basic Materials industry is the least affected, the two sectors that react the most (negatively/positively) to the events are Industry and Consumer Services. This result is reasonable because investors infer based on their general understanding that the industry in 
Vietnam is mainly the light industry, and consumer services are mainly provided in stores. Therefore, these are the two industries that are strongly affected by the characteristics of COVID-19 that are highly contagious between people in close contact. The difference of this study compared to previous studies is the response of the Consumer Goods and Utilities industry. The Utilities sector is not the best performer of all the industries as the results from previous studies show that the industry reacts negatively to two events -in terms of infections first recorded in Hochiminh city and Hanoi. It shows concern about possible damage from production disruptions in Vietnam's two major economic centers to the Utilities industry. Except for the first event, the Consumer Goods sector had the most positive results of all industries with the other two events.

\section{Implications}

The study provided a snapshot of the overall industry response to the first events of COVID-19 and the individual industry's response to each subsequent event. The existence of abnormal returns of industries related to events shows that Vietnam's stock market is not efficient. Therefore, the results from this study add to the set of decision criteria of investors to exploit the anomalies in the Vietnamese stock market. For regulators and policymakers, understanding industry responses to outbreak-related contingencies will help them be more proactive and prepare appropriately for similar events in the future.

\section{LIMITATIONS AND DIRECTIONS FOR FUTURE RESEARCH}

This study provides insights into the stock price reactions of sectors on the Vietnam stock market, compares and contrasts stock price reactions across sectors through events affecting public health. However, the dataset currently mainly focuses on companies listed on the stock market, which shows the limitation of the study. Therefore, future research directions can overcome this limitation by using the data of the whole company in each industry or expanding the research by industry at the level of countries.

\section{REFERENCES}

1. Baker S.R., Bloom N., Davis S.J., Kost K., Sammon M., Viratyosin T. The unprecedented stock market reaction to COVID-19. The Review of Asset Pricing Studies. 2020;10(4):742-758. DOI: 10.1093/rapstu/raaa008

2. He P., Sun Y., Zhang Y., Li T. COVID-19's impact on stock prices across different sectors - An event study based on the Chinese stock market. Emerging Markets Finance and Trade. 2020;56(10):2198-2212. DOI: 10.1080/1540496X.2020.1785865

3. Smales L.A. Investor attention and the response of US stock market sectors to the COVID-19 crisis. Review of Behavioral Finance. 2021;13(1):2039. DOI: 10.1108/RBF-06-2020-0138

4. Bouri E., Naeem M.A., Nor S.M., Mbarki I., Saeed T. Government responses to COVID-19 and industry stock returns. Ekonomska Istraživanja = Economic Research. 2021. DOI: 10.1080/1331677X.2021.1929374

5. Göker İ.E.K., Eren B.S., Karaca S.S. The impact of the COVID-19 (coronavirus) on the Borsa Istanbul sector index returns: An event study. Gaziantep University Journal of Social Sciences. 2020;19:14-41. DOI: 10.21547/jss.731980

6. Phuong L.C.M. How COVID-19 impacts Vietnam's banking stocks: An event study method. Banks and Bank Systems. 2021;16(1):92-102. DOI: 10.21511/bbs.16(1).2021.09

7. Phuong L.C.M. How COVID-19 affects the share price of Vietnam's pharmaceutical industry: Event study method. Entrepreneurship and Sustainability Issues. 2021;8(4):250-261. DOI: 10.9770/ jesi.2021.8.4(14)

8. Fama E. F. Efficient capital markets: A review of theory and empirical work. The Journal of Finance. 1970;25(2):383-417. DOI: 10.1111/j.1540-6261.1970.tb00518.x

9. Malkiel B. Efficient market hypothesis. In: Newman P., Milgate M., Eatwell J., eds. The new Palgrave dictionary of money \& finance. London: The Macmillan Press Ltd; New York: The Stockton Press; 1992. DOI: 10.1057/978-1-349-95121-5_42-1

10. Tversky A., Kahneman D. Judgment under uncertainty: Heuristics and biases. Science. 1974;185(4157):11241131. DOI: $10.1126 /$ science.185.4157.1124

11. Kahneman D., Tversky A. Prospect theory: An analysis of decision under risk. Econometrica. 1979;47(2):263292. DOI: $10.2307 / 1914185$

12. Baker H.K., Nofsinger J.R. Behavioral finance: An overview. In: Baker H.K., Nofsinger J.R., eds. Behavioral finance: Investors, corporations, and markets. Hoboken, NJ: John Wiley \& Sons; 2010:1-21. DOI: 10.1002/9781118258415.ch1 
13. Brav A., Geczy C., Gompers P.A. Is the abnormal return following equity issuances anomalous? Journal of Financial Economics. 2000;56(2):209-249. DOI: 10.1016/S 0304-405X(00)00040-4

14. Spence M. Job market signaling. The Quarterly Journal of Economics.1973;87(3):355-374. DOI: $10.2307 / 1882010$

15. Connelly B.L., Certo S.T., Ireland R.D., Reutzel C.R. Signaling theory: A review and assessment. Journal of Management. 2011;37(1):39-67. DOI: 10.1177/0149206310388419

16. Ross S.A. The determination of financial structure: The incentive-signalling approach. The Bell Journal of Economics. 1977;8(1):23-40. DOI: 10.2307/3003485

17. Shen H., Fu M., Pan H., Yu Z., Chen Y. The impact of the COVID-19 pandemic on firm performance. Emerging Markets Finance and Trade. 2020;56(10):2213-2230. DOI: 10.1080/1540496X.2020.1785863

18. Budiarso N.S., Hasyim A. W., Soleman R., Zam I.Z., Pontoh W. Investor behavior under the COVID-19 pandemic: The case of Indonesia. Innovations. 2020;17(3):308-318. DOI: 10.21511/imfi.17(3).2020.23

19. Phuong L.C.M. Stock price reactions to information about top managers. Banks and Bank Systems. 2021;16(2):159-169. DOI: 10.21511/bbs.16(2).2021.15

20. Phuong L.C.M. The impact of COVID-19 on stock price: An application of event study method in Vietnam. The Journal of Asian Finance, Economics and Business. 2021;8(5):523-531. DOI: 10.13106/jafeb.2021. vol8.no5.0523

21. Haroon O., Rizvi S.A.R. COVID-19: Media coverage and financial markets behavior - A sectoral inquiry. Journal of Behavioral and Experimental Finance. 2020;27:100343. DOI: 10.1016/j.jbef.2020.100343

22. Ramelli S., Wagner A.F. Feverish stock price reactions to COVID-19. The Review of Corporate Finance Studies. 2020;9(3):622-655. DOI: 10.1093/rcfs/cfaa012

23. Thorbecke W. The impact of the COVID-19 pandemic on the US Economy: Evidence from the stock market. Journal of Risk and Financial Management. 2020;13(10):233. DOI: 10.3390/jrfm13100233

24. Phuong L. C.M. Food and beverage stocks responding to COVID-19. Investment Management and Financial Innovation. 2021;18(3):359-371. DOI: 10.21511/imfi.18(3).2021.30

25. Kothari S.P., Warner J.B. Measuring long-horizon security price performance. Journal of Financial Economics. 1997;43(3):301-339. DOI: 10.1016/S 0304-405X(96)00899-9

26. Strong N. Modelling abnormal returns: A review article. Journal of Business Finance \& Accounting. 1992;19(4):533-553. DOI: 10.1111/j.1468-5957.1992.tb00643.x

27. Klein A., Rosenfeld J. The influence of market conditions on event-study residuals. Journal of Financial and Quantitative Analysis. 1987;22(3):345-351. DOI: 10.2307/2330968

28. Beaver W.H. Econometric properties of alternative security return methods. Journal of Accounting Research. 1981;19(1):163-184. DOI: 10.2307/2490967

29. Brenner M. The sensitivity of the efficient market hypothesis to alternative specifications of the market model. The Journal of Finance. 1979;34(4):915-929. DOI: 10.2307/2327056

\section{ABOUT THE AUTHOR / ИНФОРМАЦИЯ ОБ АВТОРЕ}

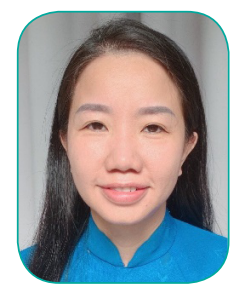

Lai Cao Mai Phuong - Dr. Sci. (Econ.), Lecturer, Faculty of Finance and Banking, Industrial University of Hochiminh City, Hochiminh, Vietnam

Лай Цао Май Пхуонг - доктор экономических наук, преподаватель, факультет финансов и банковского дела, Промышленный университет города Хошимин, Хошимин, Вьетнам

https://orcid.org/0000-0002-2947-2488

laicaomaiphuong@iuh.edu.vn

Conflicts of Interest Statement: The author has no conflicts of interest to declare.

Конфликт интересов: автор заявляет об отсутствии конфликта интересов.

The article was submitted on 28.09.2021; revised on 14.10.2021 and accepted for publication on 17.01.2022.

The author read and approved the final version of the manuscript.

Статья поступила в редакцию 28.09.2021; после рецензирования 14.10.2021; принята к публикации 17.01.2022. Автор прочитала и одобрила окончательный вариант рукописи. 